\title{
Interest Rate Controls-Perspective, Purpose, and Problems
}

T HROUGHOUT MOST of this nation's history, usury laws and other interest rate restrictions have had little impact on credit flows. In recent years, however, such restrictions have interfered increasingly with credit markets. The restrictiveness of legal limits is being felt over wide areas, as a result of a rapid rise in market rates of interest to levels that are above ceilings set by usury laws and other government controls. These restrictions have been ameliorated, however, as maximum permissible rates payable by banks on deposits have been increased a number of times dur ing the past decade when market rates exceeded their ceilings. ${ }^{1}$

In 1957 the Federal Reserve Board, for the first time since being granted the authority in 1933, increased the maximum permissible rates paid by member banks on time and savings deposits. Since 1957, the Board has increased maximum permissible rates seven times as market rates have risen.

Interest rate restrictions on funds flowing into financial agencies, which for many years were applied exclusively to banks, have recently been extended to include maximum rates payable by some nonbank financial intermediaries. The 1966 Interest Rate Act directed the Federal Reserve Board, the Secretary of the Treasury, the Federal Home Loan Bank Board, and the Federal Deposit Insurance Corporation to take action to reduce interest rates to the extent feasible, given the prevailing money market and economic conditions. The Federal Reserve Board was given the power to set different ceiling rates for different classes of bank deposits. Exercising this broadened authority, the Board reduced the maximum rate on consumer-type certificates of deposit to 5 per cent. In 1966 the FDIC for the first time set maximum interest rates for mutual savings banks, and the Home Loan Bank Board applied dividend restrictions to the savings and loan associations.

Despite this broadening of restrictions, a large percentage of funds has continued to flow through financial intermediaries in response to supply and demand

\footnotetext{
Federal Reserve Bulletin, July 1968 , p. A-11. Since February 1936, maximum rates that may be paid by insured nonmember banks have been the same as those for member banks.
}

forces. Many financial agencies, such as the farm credit banks, sales finance companies, and nonfinancial corporation lenders, remain outside Federal controls on rates payable, though subject to state usury laws on rates charged.

Lending rates of banks, savings and loan associations, and individuals are also subject to state usury laws, which impose limits which recently have been below market rates in many states. Although some areas of free market rates remain, controls are creating diversions in credit flows. The 6 per cent limit imposed on commercial bank loans in several states tends to reduce the flow of commercial bank credit to customers. Limits at the national level on rates paid by banks and savings and loan associations for funds slow the growth rate of these intermediaries.

This article accepts the basic economic premise that free markets lead to an optimum allocation of resources. It concludes that interferences with normal credit flows create inefficiencies in the financial markets that have an adverse impact on the distribution of capital and consumer goods.

Such inefficiencies in resource use can be explained within the framework of a free market. The market determines the returns to savers and allocates loanable funds among borrowers. These returns and allocations are made on the basis of supply and demand conditions. Supplies of loanable funds are determined by savings and the increments of credit created by monetary action. Many savers have the alternative of lending to intermediary savings-type financial agencies such as banks and savings and loan firms, or investing directly through equities, loans, bonds, etc. Expected marginal return is the major factor determining the volume of savings flows into the various channels. If interest rates payable by financial agencies are restricted to levels below the yields of alternative assets, flows of funds through them tend to decline. On the other hand, if such rates are determined by market demand, the flows supplied will expand with the rising demand for credit.

Demand for loan funds is a function of the marginal returns to capital plus the demand by individuals and government for current consumption in ex- 
cess of current income. Each demand sector is willing to purchase funds as long as marginal returns exceed costs. Efficiency in the financial market is maximized when the marginal return on funds is equal for all sectors. The price of funds (interest rate) is thus the allocator of funds both among the various sectors - business, government, and consumer - and among the various demanding units in each sector. When this allocator is inhibited, an inefficient allocation of funds occurs.

This article is a survey of interest rate restrictions in their historical setting, first outlining their rationalization as given by contemporaries of ancient, medieval, and modern times, and concluding with a statement of current reasons for controls, control problems, and the impact of controls on various sectors of the economy.

\section{Fetortical Peronective}

Restrictions on interest charges were begun in ancient times. Interest payments were observed to increase the wealth of the rich and were believed to deprive the poor. Controls consisted of both religious proscriptions and legislation which limited or forbade interest. ${ }^{2}$ Theories explaining why interest payments should be restricted were not well developed, although such payments were criticized by most philosophers.

Despite these legal and religious considerations and the strong antagonism of the philosophers, economic forces continuously fostered interest charges and payments. Economic relations had already become too complicated for gratuitous credit in much of the ancient world, and legal interest limits generally prevailed in ancient Greece. In the 4th century B.C., the Romans condoned and later fully sanctioned in terest by the institution of legal rates. ${ }^{3}$

Following the collapse of the Roman Empire, a reaction occurred with respect to interest payments. The Christian Middle Ages treated the subject of interest charges on borrowed money more thoroughly, but with the same hostility as the earlier pagans. The exploitation of poor debtors by rich creditors appeared particularly hateful to the Christian, whose religion taught him to look upon gentleness and charity as among the greatest virtues and to think little of earthly goods. The Church, step by step,

2Eugen von Bohm-Bawerk, Capital and Interest, Volume I, 4th edition, 1921, translated (South Holland, Illinois: Libertarian Press, 1959), p. 10.

${ }^{3}$ Sidney Homer, A History of Interest Rates, (New BrunsWick, New Jersey: Rutgers University Press, 1963), p. 52. managed to introduce legislation prohibiting interest payments. Secular legislation finally fell almost entirely under the Church's influence, and severe interest rate statutes emerged, thus abrogating the more liberal Roman law. ${ }^{4}$

Despite the charitable instincts of the Church, businessmen were generally able to prevent the enactment of laws which carried the interest limitation principle to its ultimate conclusion. Exceptions included the privilege of public pawnbrokers, transactions by other types of banks, the indulgence in usury practices by the Jews, and the payment of interest without its being written into the contract. Lending practices which involve hidden interest and which circumvent legal restrictions are thus not peculiar to the present generation.

By the early 14th century, economic activity had quickened and personal freedom was on the upswing. Although beliefs about interest had not changed, practical compromises were beginning to appear. Luther, Zwingli, and other reformers, while believing that interest was a parasitic gain, consented to its payment within limits. This practical compromise was justified by the argument that interest could not be conveniently eradicated because man was considered so imperfect. ${ }^{\tilde{}}$

About the middle of the 16 th century, students began to examine the theoretical foundations of severe interest restrictions. Calvin rejected the scriptural basis for interest prohibition on the ground that some passages of Scripture are interpreted differently, while others are invalid because of changed circumstances. He further pointed out the similarity of interest payments to lenders and the use of money to purchase land on which a return is anticipated. Nevertheless, he believed in interest rate controls and adherence to terms established by law. Molinaeus, a French jurist, went further, refuting point by point both the pagan and scholastic doctrines of interest prohibition. ${ }^{6}$ He maintained that the use of money yields a service, that this service is the "fruit" of money, and that the lender is injured because of use foregone.

In the 1700 's, theories related to interest developed rapidly. Turgot, a French economist, made perhaps the greatest contribution. ${ }^{7}$ He carried Calvin's interest

\footnotetext{
${ }^{4}$ Bohm-Bawerk, p. 12.

${ }^{5} \mathrm{R}, \mathrm{H}$. Tawney, Religion and the Rise of Capitalism, (New York: The New American Library of World Literature, Inc., 1950$)$, p. 18.

6Ibid., p. 20.

7 Joseph A. Schumpeter, History of Economic Analysis, (New York: Oxford University Press, 1954), p. 332.
} 
analogy a step further, pointing out that money is the equivalent of a piece of land yielding a certain percentage of the capital sum. The owner will therefore not be inclined to invest his capital in other enterprises unless he can expect a net return as great as he would obtain through the purchase of land. ${ }^{8}$ Turgot also noted that an increase in the quantity of money which raises commodity prices might increase the rate of interest." He thereby pointed to the possibility of a positive real return on money, and that price inflation might become imbedded in the nominal rate of interest.

Following the breakdown of the hard tenets of scholastic doctrine as a result of economic analysis and the rising commercial demands for credit in the 1700 's, legal restrictions on the payment of interest were generally relaxed. Most nations, however, established legal maximum usury rates. In 1545 England repealed the prohibition of interest and replaced it with a legal rate. The prohibition was later reimposed, but in 1571 it was again repealed and has never again been reinstated. The Netherlands yielded to repeal before 1600 , and is an example of a sophisticated economy that developed without the shackles on interest rates required by the scholastic doctrine. Germany, with a somewhat slower commercial development, repealed the interest prohibition about the mid-1600's. Repeal came later in Italy and France where canonistic influence was more persistent in both theory and practice.

With the exception of England, laws imposing a maximum on chargeable interest rates have persisted in most European countries. In England these laws, along with other restrictions on commerce and trade, came under intense pressure in the 1800's. Usury laws were suspended entirely in 1830 for bills under three months' maturity and were repealed for all forms of credit in $1854 .^{10}$

\section{Early Practices in the Untwol Srates}

Under the influence of the European powers, the American colonies adopted the traditions of their homeland with respect to usury. Reasons were apparently unnecessary for the continuance of this vestige of medieval and ancient views. For those who failed to recognize the limits possible under competitive conditions, restrictions were a compromise between the necessities of commerce and industry and earlier custom and belief. Protection of the "poor" bor-

\footnotetext{
8Bohm-Bawerk, p. 41.

9Schumpeter, p. 332.

10 Homer, p. 187.
}

rower against exploitation by the "wealthy" lender remained a central core of most usury legislation. Legal maximums were viewed as a means of restraining the natural appetite of the lender, and the interest received was considered a gratuity resulting from the magnanimous nature of the state. The services performed by capital continued to go unrecognized by the public.

Most of the early colonies followed the English custom of establishing a legal maximum of 6 per cent, a rate that still survives in a number of states. In most states, however, usury rates have been increased, and in a few states limits on commercial bank loans have been completely eliminated (Table 1). Four of the five states which currently have no maximum limits, namely Connecticut, Maine, Massachusetts, and New Hampshire, were settled early and established the low 6 per cent maximum as colonies. Furthermore, none of the states which developed later west of the Mississippi River established maximum interest rates at the relatively low 6 per cent level.

\section{Later United States Restrictions}

In addition to the usury laws, which were a carryover from previous ages, many states in the 20th century set ceilings on the interest rates that banks could pay on deposits. These ceilings were usually imposed in connection with deposit insurance programs. Maximum interest rates permissible for state banks were, in some states, set at a lower level than

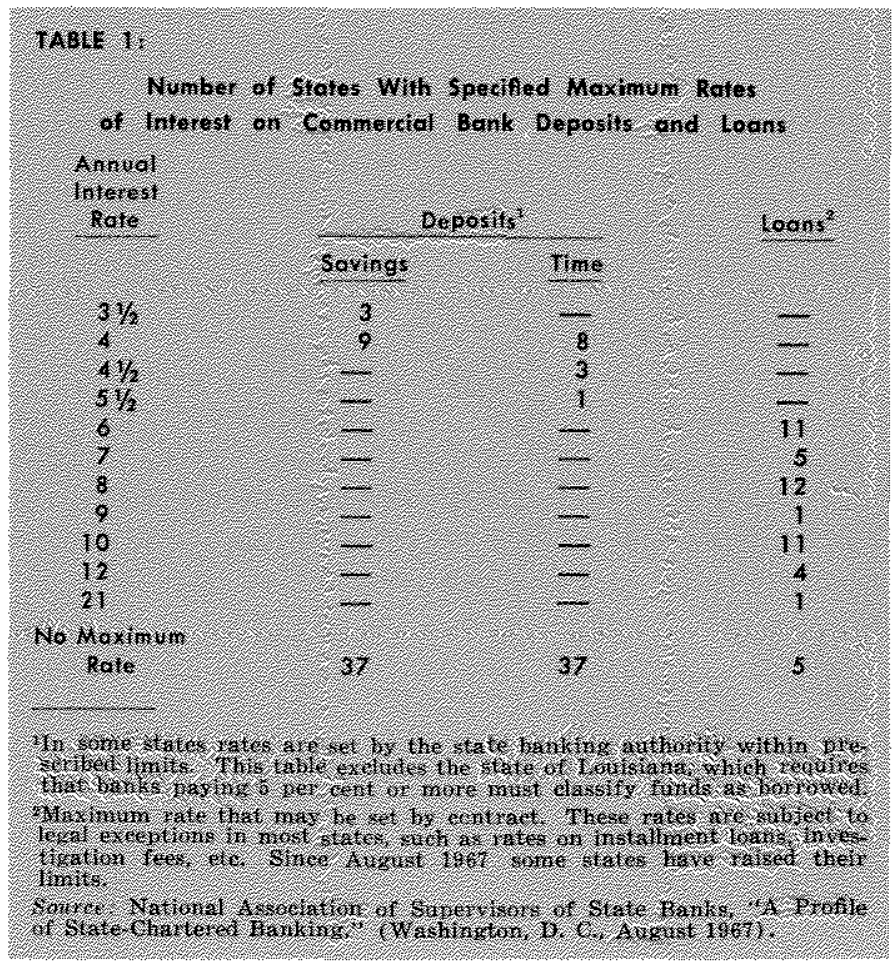


those paid by national banks. To remedy this situation, the Federal Reserve Act was amended in 1927, limiting the rates paid by national banks on time, savings, and other deposits to the maximum permitted state banks in the same state. "Following the ensuing depression of the early 1930 's, the Banking Act of 1933, with little discussion, prohibited member bank payment of interest on demand deposits and gave the Federal Reserve Board authority to set maximum rates on time and savings deposits for all member banks. These limitations were extended to nonmember insured banks by the Banking Act of 1935.

Reasons for interest rate restrictions given during the hearings related to the Banking Acts of 1933 and 1935 fell into three general categories. First, a reduction of interest rates payable by banks would tend to reduce the rates charged to bank customers. Second, interest restrictions, especially the prohibition of interest on demand deposits, would prevent the movement of funds from smaller to larger communities, and more funds would remain in the small rural communities to meet local demands. Third, restrictions on rates payable would prevent the excessive bidding up of rates which in turn leads to high-return, highrisk assets and bank failures.

Dr. Oliver M. W. Sprague, Professor of Banking and Finance, Harvard University, presented the first view. Concerning the "need" for lower interest rates, he said: ". . I should look for it to be brought about, more, through the moderate rate of interest that banks may pay on deposits . .."12 Marriner Eccles, Chairman of the Federal Reserve Board, testified: "Fixing the maximum rate of interest on deposits tends to bring down the rate on loans. That is the effect." ${ }^{\prime 13}$ Similar views were expressed by Senator Smith W. Brookhart of Iowa, a member of the Committee on Banking and Currency, and Harry J. Haas, President of the American Bankers Association. ${ }^{14}$

The second view, that the prohibition of interest on demand deposits prevents the movement of funds to financial centers, was presented by Senator Carter Glass of Virginia, Chairman of the Subcommittee

\footnotetext{
11Amendment to the Federal Reserve Act, section 24, dated February 25, 1927 (44 Stat. 1224, ch. 191).

12 Hearings Before a Subcommittee of the Committee on Banking and Currency, United States Senate, Seventyfourth Congress, First Session on S-1715, Part 1, April 19 to May 13, 1935, p. 217.

13Hearings Before the Committee on Banking and Currency, House of Representatives, Seventy-fourth Congress, First Session on H. R. 5357, February 21 to April 8, 1935, p. 330.

1 Hearings Before the Committee on Banking and Currency, Seventymsecond Congress, First Session on \$-4115, Part I, March 23-25, 1932.
}

on Monetary Policy, Banking, and Deposit Insurance. Speaking on the floor of the Senate in 1933, Senator Glass said: ". . this payment of interest, particularly on demand deposits, has resulted in drawing the funds from country banks to the money centers for speculative purposes." ${ }^{\prime \prime}$ Similar views were expressed by Congressman Patman of the Committee on Banking and Currency, ${ }^{16}$ and by Ronald Ransom, Vice Chairman, Board of Governors of the Federal Reserve System. ${ }^{17}$

A third thread extending throughout the hearings prior to the Banking Acts of 1933 and 1935 was that interest rate restrictions were essential to prevent the excessive bidding up of rates. Benjamin M. Andersen, $\mathrm{Jr}$, economist with the Chase National Bank, said: "The only place where a definite abuse existed that needed public regulation was time deposits." Senator McAdoo stated: "The bidding by banks against each other for the deposits of customers who had large deposits ... led to unwholesome competition between banks and an unwholesome condition so far as demand deposits were concerned."18 Leo T. Crowley, Chairman of the Federal Deposit Insurance Corporation, said: ". . . in years gone by, banks paid as high as 4,5 , and 6 per cent for what we would term 'time deposits'. They offered all kinds of premiums, like blankets and clocks..., and the banks which perhaps should not have paid those high interest rates were the ones that were the most apt to offer the depositor an interest rate that was not sound."19

In 1966 a fourth reason for the control of rates payable on time and savings deposits was developed - the elimination of unsound competition between banks and other financial intermediaries. In hearings on the Interest Rate Act of 1966, excessive competition was the principal subject of discussion. Norman Strunk, Executive Vice President of the United States Savings and Loan League, reported: "The adverse effect on the flow of savings into savings and loan associations and savings banks has been severe and the situation is worsening monthly. Those commer-

\footnotetext{
I5Ouoted in Hearings Before the Committee on Banking and Currency, House of Representatives, Seventy-eighth Congress, Second Session on H. R. 3956, December 10, 1943 to 1 february 9,1944, p. 2 .

16 Ibid., p. 679 .

17 Ibid., p. 16.

18Hearings Before a Subcommittee of the Committee on Banking and Currency, United States Senate, Seventyfourth Congress, First Session on S-1715, Part II, May 1422, 1935, pp. 490-91.

${ }^{19 H e a r i n g s ~ B e f o r e ~ t h e ~ C o m m i t t e e ~ o n ~ B a n k i n g ~ a n d ~ C u r-~}$ rency, House of Representatives, Seventy fourth Congress, First Session on H. R. 5357, February 21 to April 8, 1935, p. 86.
} 
cial banks unable or unwilling to compete at the new rates are equally affected.

"The commercial banks, as short-term lenders with their funds invested in short-term business loans and high-interest-rate consumer loans, are able to charge more in periods of high interest rates, and commercial bank loans can be adjusted to higher interest rates more readily. Bank eamings, thus, can increase very rapidly in periods of rising short-term interest rates, and banks can pay higher rates on savings." 20 Similar views were expressed by John E. Home, Chairman of the Federal Home Loan Bank Board. ${ }^{21}$

In addition to the need for restraining competition between banks and other financial agencies, Larry Blackmon, President of the National Association of Home Builders, emphasized the merit of giving first preference for savings to homeowners. ${ }^{22}$ The need for at least temporary restraint on competition for funds was expressed by the Council of Economic Advisers. ${ }^{23}$

The Interest Rate Regulation Act of 1966, which was passed following these hearings, directed the supervisory authorities to take action to bring about a reduction of interest rates to the maximum extent feasible in the light of current money market and economic conditions. It authorized the Board of Governors of the Federal Reserve System and the Federal Deposit Insurance Corporation to prescribe different rate limitations for different classes of bank deposits, and also provided for regulating rates paid by mutual savings banks and dividends on savings and loan association shares.

\section{The Effects of Usury Laws}

An analysis of reasons for interest restrictions by ancient, medieval, and modern societies reveals the heavy influence of ethical and moral considerations. These considerations were heavily weighed in favor of low interest rates which were generally believed obtainable through legislation. The actual impact of usury legislation, however, probably has been contrary to the intended impact. Instead of providing lower cost credit, such laws have often retarded credit flows. The result has been a scarcity of credit available for many vital activities.

\footnotetext{
20Hearings Before the Committee on Banking and Currency, Eightyminth Congress, Second Session on H. R. 14026, May 9 to June 23,1966, pp. $7-8$.

21 Ibid., p. 72 ,

221 bid., p. 263.

23 lbid., p. 429.
}

\section{Usury Restrictions Retard Home Constuchon}

Attempts by states to restrict interest payments have been frustrated by the interconnection of credit markets. Low ceiling rates, instead of fostering credit to the poor and for local economic development, have fostered the export of capital to other areas, despite the great demand for credit locally. Harry L. Johnson, in an article on conditions in Tennessee where low limits are placed on both usury rates and rates payable by banks, reports: "Among the more immediate and discernible economic ills which have ocourred in the past and which will be aggravated by unrealistic limitations on interest rates are: (1) a decline in residential building, (2) an increase in the level of unemployment in construction, (3) a decline in the sales of building supplies, (4) an outflow of savings, (5) an increase in the rate of interest and yields on bonds issued by the State of Tennessee and its political subdivisions, and (6) increased competition for Tennessee's financial resources by out-of-state individuals and businesses." ${ }^{34}$ The maintenance of low legal maximum rates on commercial loans might be expected to foster industrial development and economic growth. Most of the 11 states with the lowest legal limit (6 per cent), however, are not noted for wealth and vigor, or for the ease of credit conditions for the poor. About half of them are located in the Appalachian Area. ${ }^{25}$

Credit for home mortgages is affected adversely in states with low usury ceilings. In a speech before the Pennsylvania Bankers Association, Andrew F. Brimmer, Member of the Board of Governors of the Federal Reserve System, pointed out the adverse effects of low ceiling rates on credit flows into the home mortgage market. He stated that the reduction in the supply of funds tends to reduce activity in home building and the transfer of existing dwellings. ${ }^{26}$

The total volume of funds for lending is curtailed in states with low usury rate ceilings. Loanable funds search for areas of highest returns. Funds in low rate ceiling states tend to move to other states and to

${ }^{24}$ See Harry L. Johnson, "An Island Unto Atself," Tennessee Survey of Business, the University of Tennessee, Volume III, No. 7, March 1968.

25States with the 6 per cent linit as of Augtst 1967 were: Delaware, Kentucky, Maryland, New Jersey, New York, North Carolina, Pennsylvania, Tennessee, Vermont, Virginia, and West Virgiria. Since then some of the above states have raised their limits.

20Andrew F. Brimmer, "Statutory Interest Rate Ceilings and the Availability of Mortgage Funds," Federal Reserve Bank of Philadelphia, Supplement to Business Review, June 1968.

Page 10 
non ${ }^{-c}$ credit demands. Financial intermediaries in such states cannot effectively compete for savings, as the limited returns on loans do not transmit the free market signals to savers. The limited volume of funds flowing into such agencies results in a reduced level of loans.

\section{Credit to Low Income Groups Reduced}

Credit is more difficult for low income groups to obtain in states with low usury ceilings. Loanable funds, when restricted to low interest rates, do not seek out poor borrowers whose security is less adequate and whose repayment capacity is limited. Such credit Hows more readily to borrowers with adequate assets for pledging. These borrowers can demand larger low-risk loans with handling costs at a minimum. Consequently, instead of protecting high-risk borrowers from high rates, usury laws actually prevent those borrowers from acquiring funds, or force them to seek illegal or less efficient sources.

\section{Venture Credit Impeded}

Venture or development credit, which is also risky, is retarded in states with severe usury laws. Such credit can only be extended at a higher rate of interest to offset the higher risk. In states with low maximum rates, no means to offset high risks are available. Usury laws are relatively harmless when market rates are low relative to the legal maximums, i.e., when the usury rates are not effective. They are harmful to all concerned when doing the job for which they were designed-limiting the rates chargeable.

The volume of credit flowing to low-risk individuals and well-established businesses may be almost as great under severe usury restrictions as under free market conditions. Low usury ceilings prevent other individuals and firms from effectively bidding for funds. With the higher risk users in effect excluded from the market, most funds will probably flow to lowrisk individuals and firms.

\section{Limits on Rates Payable to Savers Restrict Credit Flows}

Like usury laws, many restrictions on rates payable have their roots imbedded in ancient and medieval thought. For example, the belief that a reduction in interest rates payable by banks on deposits tends to reduce rates charged bank customers (and that this is a worthy objective) implies that low charges to debtors are preferable to high returns to savers. A look at the credit market indicates that the richcreditor, poor-debtor implications carried over from the Middle Ages may not hold in modern economies.

\section{The Roh-Creditor, Boor-Deblor Mallacy}

Instead of the rich leaving funds in the banks" custody to loan out to poor borrowers, the reverse may be closer to the facts. In 1957 more than half of all member bank business credit was extended to firms with net worths of $\$ 50,000$ and over, ${ }^{27}$

Investment of savings through banks and savings and loan associations has not led to the accumulation of great wealth during the period of national controls on rates payable. For example, an investment of $\$ 10,000$ in 1934 in savings deposits at ceiling rates, with 75 per cent of earnings reinvested annually, would have been worth $\$ 20,239$ in 1967. Similar investments in Standard and Poor's composite list of common stocks and farm land would have been worth $\$ 232,530$ and $\$ 271,476$, respectively. At constant prices based on the Gross National Product price deflator, the savings deposit yield was negative, whereas the investments in common stocks and farm land rose 8 and 9 fold, respectively. These data indicate that great wealth has not been accumulated from savingstype investments in recent years. On the other hand, a large proportion of such depositors was in the middle and lower economic classes and had few alternative opportunities for investment.

\section{Low Rates bo Swers May \\ Cause Higher nates io Bontrowers}

In addition to the rich-poor fallacy, the causation assumed in the "low rates paid to savers lowers rates to borrowers" argument is questionable. Legal maximum rates, which are effective in holding rates below levels that banks and other financial agencies can afford to pay under competitive conditions, tend to reduce the How of funds through normal channels and to divert savings into non-credit uses such as bonds, equities, real estate, etc. The smaller supply of funds moving into the credit market will meet an equal amount demanded at higher rates. Borrowers must pay the higher rates to obtain funds. Attempts to lower the rates to borrowers by limiting their opportunity to compete for funds is comparable to efforts to lower food prices by limiting the amount that farmers can spend on production. Total costs could

\footnotetext{
27"Member Bank Lending to Small Business," Federal Reserve Bulletin, April 1958, p. 396.
} 
be lowered, but output and consumption would decline, and prices of farm products and food would be increased.

A reduction in the flow of funds through efficient financial agencies and the consequent higher prices retard economic growth. Credit's contribution to growth is maximized when scarce credit resources flow most efficiently to areas where returns are greatest. Rates offered savers then transmit consumer and business demands for credit. When market rates exceed the legal maximum permitted, the appropriate signal is not transmitted to savers, and flows of funds are diverted from normal channels. Flows through the credit market decline and a greater portion of savings moves into equities, real estate, bonds, and direct loans. Credit-using activities which comprise a major part of economic growth are thus retarded. This diversion of credit flows and the consequent growth retardation are especially severe in the case of state restrictions, since funds are not only diverted to non-credit uses, but to credit uses in surrounding states.

\section{Market Rates Distibute \\ Credit to All Areas}

The second reason for restricting interest rates payable - that uncontrolled rates paid tend to dry up loanable funds in rural areas and cause excessive concentrations of funds in the largest cities - is like wise questionable. It was contended that the speculators who borrowed funds in the largest cities could outbid borrowers in the smaller communities. Farmers, rural merchants, and other citizens would thus be without available credit, whereas bountiful supplies could be found in the large cities available to the speculators. This conception of the financial market is not consistent with the facts. The large financial agencies which gather funds are often located in the large centers, but they gather savings from both rural and urban areas, and under free market conditions distribute funds to areas where marginal returns are greatest. Rural areas have demonstrated their ability to compete for funds in national markets when provided with access to such markets. The farm credit banks are good examples of the ability of rural communities to compete for funds in the money market centers. Commercial banks likewise gather funds from savers in all areas and distribute them to areas of greatest marginal returns insofar as the banking structure permits. In some instances these distributions are in the form of direct loans, while in other cases funds are distributed to ultimate users through other financial agencies such as the farm credit banks.

\section{Danger of Institutions Falling Overstated}

The third argument for restricting rates payablethat high rates paid on savings force financial institutions into high-risk investments and ultimate failure - dates back to the early thirties. Its proponents see nothing that will serve to break the rise in rates paid on deposits when banks begin to bid against one another for funds. It is argued that the banks are compelled to take one imprudent investment step after another until asset risks reach intolerable levels and depositors' funds are ultimately lost. However, little evidence to confirm this view has been forthcoming.

George Benston found no relationship between interest rates paid on deposits and gross rate of return on investments. ${ }^{28} \mathrm{He}$ also found no relationship between average rates paid by banks and average risks of their portfolios, as measured by ultimate write-offs of investments. Contrary to the expectations of the high-rate, high-risk thesis, he found that interest rates paid were substituted at the margin for other operating expenses such as salaries, facilities, automated machinery, advertising, etc.

Profit maximization by banks, as in other firms, provides a more rational explanation of bank behavior. Banks are likely to use the same criterion in deciding what rate of interest to offer as they use in making other decisions relative to expense. In making decisions on hiring additional workers, they base their decisions on the expected value of services performed. They are likely to continue to hire additional help as long as the gain in value of services exceeds all costs associated with the additional labor. Marginal costs and returns, with due allowance for risks, also determine the level of interest rates that a bank decides to pay. Otherwise, the bank is not maximizing. Haywood and Linke conclude in a recent publication that "when stripped of the folklore that has grown up around it, the relevant rationale of deposit interest regulation in 1933 was price fixing, which was somewhat in vogue at the time as an anti-depression measure." ${ }^{n g}$

\section{A Costly Method of Protecting Financial. Intermediaries}

A more recent argument given for controlling interest rates payable on deposits at financial inter-

28George J. Benston, "Interest Payments on Demand Deposits and Bank Investment Behavior," Journal of Political Economy, October 1964, pp. 431-449.

${ }^{29}$ Charles F. Haywood and Charles M. Linke, The Regulation of Deposit Interest Rates, a study prepared for the Trustees of the Banking Research Fund, Association of Reserve City Bankers, (Chicago, Illinois: June 15, 1968), p. 3 . 
mediaries is that sizable increases in rates paid may cause substantial hardship to savings and loan associations. In addition to destructive internal competition, destructive external competition has become a reason for restricting rates payable. It is contended that hardships would be especially severe on savings and loan associations because of the long-term nature of their assets and the short-run contracts on funds purchased. The average interest rate paid on all deposits rises immediately as rates offered increase, whereas returns increase only on new mortgage additions to the portfolio. Average earnings thus rise much more slowly than expenses.

The need for rate controls for this purpose may be questioned. The book value of aggregate reserves and undivided profits of savings and loan institutions is currently nearly twice the size of their yearly dividend payments. They also have cash and government security holdings from which payments could be made totaling over double their yearly dividend payments. These ratios prevailed even at the end of 1966, after the associations had endured their most adverse year. This means that the average association could remain solvent in an accounting sense and pay its dividends for nearly two years, even though it had no net profits. ${ }^{30}$

Investing on a long-term basis with short-term funds apparently calls for a substantial amount of liquidity, Such liquidity can be either in the form of short-term loans or other short-term assets, such as government bonds, etc. If changes in savings and loan restrictions are necessary to provide greater liquidity, such changes are preferable to rate rigidities which deprive the community of the benefits of rate competition. Furthermore, other opportunities, such as maximum assistance from the Federal home loan banks during periods of stress, have apparently not been fully exploited. With 12 to 15 per cent of the portfolios of savings and loan associations turning over each year, assistance from the Home Loan Bank, coupled with a permissible reduction in reserves, should take care of most periods of interest rate rises for the major portion of savings and loan associations. These associations have considerable ability to with. stand these periods when terms of trade are adverse. Furthermore, on the downside of interest rates, rapid accumulations of reserves can be made, offsetting losses on the upside of rate movements, and the Home Loan Bank can be repaid and reserves recouped.

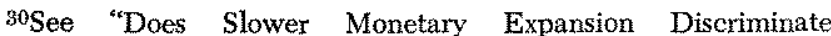
Against Housing" by Norman $N_{r}$ Bowsher and Lionel Kalish in the June 1968 issue of this Review.
}

Rate controls may have been the most important factor contributing to the slowdown in the housing industry during the recent periods of sharply rising general interest rates. Rising rates make yields on saving accounts at controlled levels less attractive than rates paid in the free market. There have been several setbacks in the rate of increase of savings capital of these institutions during periods of relatively high or rising interest rates. In only one quarter, however, (third quarter, 1966, during which rate controls were put into effect) was there a moderate net decline. To the extent that rate controls reduced credit flows into the savings and loan industry, they affected housing adversely.

Appropriate monetary and fiscal policies are also important factors in maintaining the stability of savings and loan associations. Sharp increases in interest rates during recent years have been associated with rising prices. The real rate of return on loans and investments has been relatively stable. The rising prices can be associated with expansive fiscal and monetary actions. Thus, an important factor in maintaining relatively stable interest rates is the maintenance of fiscal and monetary policies that are conducive to stable prices.

If, as a final resort, other means are necessary to prevent widespread failures in savings and loan associations, direct Government loans through the Federal Home Loan Bank System are preferable to interest rate controls. Such assistance could be given only to the weak associations which had not adequately prepared for adverse economic conditions. In contrast to helping only the weak, rate controls widen the spread for all associations, and prevent rate competition within the banking community, and between savings and loan associations and banks. Thus, the public loses the benefit of rate competition and at the same time loses the benefit of the potential growth of both associations and banks during periods of sharply rising rates.

A major effect of rate controls is the limitation of the size of controlled firms, which in turn causes a more rapid growth in flows of funds which are not controlled. Rate restrictions thus may not be profitable to the agencies restricted. With the slower growth rate, bank earnings are likely to be less over the longer run, and savings and loan associations will perform a declining function in the economy. The rapid growth of farm credit at the farm credit banks relative to commercial banks in the past two years may illustrate this situation. Farm credit outstanding at production credit associations and Federal land 
banks rose at almost double the rate of farm credit expansion at commercial banks from 1965 to 1967.

\section{Summary}

Restrictions on interest rates charged and paid by competitive financial institutions are vestiges of medieval and ancient thought, and are inapplicable to modern commercial economies. They are based on false premises, operate perversely, and are economically inefficient.

The ancients banned interest for ethical reasons, the medievals for religious and moral considerations; modern restrictions are a carry over of such ideas plus a lack of confidence in market forces. Supply and demand for loan funds rather than rate controls historically have kept interest rates at moderate levels in the United States.

Ancient and medieval desires to improve the position of poor debtors relative to rich creditors may have had some basis. There is no evidence today, however, that borrowers from financial institutions are less wealthy than their saving depositors. A floor under rates paid might be more helpful to the poor than a ceiling. Usury ceilings eliminate the poor higherrisk borrowers from the credit market and thereby channel a higher percentage of loanable funds to lower-risk customers. Consequently, any alteration of rich-poor relationships made by low usury cellings is likely to be in favor of the wealthy.

All cellings which alter normal flows of funds retard economic growth. Low usury ceilings prohibit the higher rates necessary to offset the higher risks of business and individual innovators. Credit tends to be channeled into well-established, low-risk functions. Low ceilings on rates payable by financial agencies tend to restrict the flow of funds through usual credit channels. Loan fund supplies are thereby reduced, affecting borrowers adversely. Such restrictions are especially harmful to longuterm credit users, such as the housing industry, where credit is the major source of purchase money and interest an important part of the total costs.

The thesis that high rates paid cause institutions to invest in high-risk assets has little validity. Instead of contributing to imprudent banking practices, high rates may indicate flexibility and competitiveness in meeting the sound credit demands of the community. Bank failures result from numerous factors, both internal and external. External factors such as monetary and fiscal policies and regional economic conditions may result in deposit drains and loan losses. These factors were probably the major cause of the failures in the 1930's which led to rate ceilings. In any event, evidence indicates that when low legal limits are set on rates payable, banks substitute other expenses at the margin, such as advertising, attractive buildings, and gifts, where such substitutions are profitable.

The more recent reason for controls - that rate competition creates excessive hardships for savings and loan associations - is likewise difficult to uphold. It implies that a wider profit margin for banks is necessary to keep funds flowing through the savings and loan associations into the home building industry. This wider margin for banks was established despite the fact that bank failures were almost at the zero level. This type of assistance protects both the strong and the weak, inhibits price competition between the two types of firms and among firms within each group, and diverts funds to less desirable uses.

Greater liquidity in the form of more short-term assets is apparently necessary for a number of savings and loan associations. Some increase in such assets will permit the associations to weather most sharp increases in rates without excessive strain.

If some assistance is necessary for savings and loan associations, a reduction in price competition appears to be an extremely expensive type of aid. Greater assistance to the weaker associations through the Federal Home Loan Bank System would appear more appropriate.

Monetary and fiscal policies which contribute to greater price stability should alleviate most requests for assistance by savings and loan associations. Such policies will reduce the rate of inflation, which in turn is incorporated into interest rates, thus moderating rate increases.

Finally, controls on rates payable by financial agencies ignore the welfare of savers who invest through these agencies. Such savers perform a vital function in the economy. Rate controls deny many low income savers the right to a competitive loanable funds market. High income savers can bypass the controlled market by investing in equities, etc., but if rate controls cause them to divert funds or to lose interest income, their contribution to economic product is reduced.

Clifton B. Luttrell

This article is available as reprint series No. 32 . 